\title{
Design of a premix for making gluten free noodles
}

\author{
Silvana Beatriz Sabbatini, Hugo Diego Sanchez", Maria Adela de la Torre, Carlos Alberto Osella \\ Instituto de Tecnología de Alimentos, Facultad de Ingeniería Química-Universidad Nacional del Litoral, Santa Fe, Argentina
}

\section{Email address:}

hsanchez@fiq.unl.edu.ar (H. D. Sanchez)

\section{To cite this article:}

Silvana Beatriz Sabbatini, Hugo Diego Sanchez, Maria Adela de la Torre, Carlos Alberto Osella. Design of a Premix for Making Gluten Free Noodles. International Journal of Nutrition and Food Sciences. Vol. 3, No. 5, 2014, pp. 488-492.

doi: 10.11648/j.ijnfs.20140305.29

\begin{abstract}
The objective of this work was to select suitable starches and hydrocolloids to produce premixes that allow making gluten free noodles for celiac people and the evaluation of their physical, chemical and sensorial characteristics. Native and pregelatinized corn starch and the hydrocolloids xanthan gum, hydroxypropylmethylcellulose and guar gum were studied. The following aspects were analysed: dough machinability, moisture content in noodles, loss of solids by cooking, and some sensorial characteristics as taste and texture. Pregelatinized starch was selected because of its better integration of ingredients, resulting in uniform and wet dough, that devoid of tackiness thereby facilitating the rolling process. According to the obtained results with hydrocolloids, guar gum at a level of $2 \%$ is the hydrocolloid recommended to be used in making noodles for celiac people because of its good technological behaviour and that it allows obtaining noodles with the typical texture known as "al dente".
\end{abstract}

Keywords: Noodles, Starches, Hydrocolloids, Guar Gum

\section{Introduction}

Celiac Disease $(\mathrm{CD})$ is a chronic entheropathy produced by gluten intolerance, more precisely to certain proteins called prolamines, which causes atrophy of intestinal villi, malabsorption and clinical symptoms that can appear in both childhood and adulthood [1,2]. It occurs in about $1 \%$ of European people [3]. These proteins are found in wheat, oat, barley and rye. The toxic fractions adopt different names, depending on the cereal: gliadin in wheat, avidin in oat, secalin in rye and hordein in barley [2].

In our country, the statistics show that the prevalence is about 1:100 people, suggesting that this incidence of celiac disease is similar to that observed in some areas of Europe genetically related to our population [4]. When a patient begins to eat foods without gluten, there is often much confusion about which are the allowed foods. There are many gluten-free foods such as milk, butter, cream, cheese, fruits and vegetables, fresh or frozen, meat, fish, eggs, beans, nuts, corn and rice. Gluten is found mainly in breads, cereals and pastas, but also found in spices, sauces, dressings, and others. Consuming gluten free food has become easier in recent years, with increased number and quality of products available in specialty shops, but this implies a much greater expense in relation to foods containing gluten [5]. Regarding the questionable food consumption, it is necessary to consider that wheat is used to dilute processed foods, and is found in many commercially available products such as ice cream, in salad dressings such as ketchup and mustard, in canned foods like vegetables and soups, in some brands of instant coffee and in most candy [6]. In addition, most bakery products, confectionery and bakery in Argentina contain wheat flour as a main component, then the celiac patient encounters limitations in their food [6,7].

Noodles are foods with high acceptability worldwide because they are part of the diet of many populations and are relatively inexpensive and easy of preparation [8]. This may be also considered as a functional food because of their low content of fat and sodium. [9,10]. There are in the market, suitable foods for celiac people that among other ingredients contain corn starch, potato starch, tapioca starch and rice flour. In the particular case of making noodles, there are experiences where have been used in very acceptable form, raw materials as defatted corn germ and beans to replace durum wheat semolina [11]. In general the use of starches, gums and hydrocolloids are the most suitable means to make the gluten replacement in products for celiac people $[12,13,14]$. Rice is also a good raw material to design formulations without gluten, is thought 
that this cereal provides $20 \%$ of dietary energy supply of the world. Not only is a rich source of energy but also is a good source of vitamin B such as thiamine, riboflavin and niacin. Besides, in consideration of the amino acid profile, while it has a high content of glutamic and aspartic acid it also has a low content of lysine which is a limiting amino acid [15]. Noodles prepared from flours of rice varieties different were acceptable but they showed large variation in texture quality [16].

Cassava starch is extensively used in the diet of the celiac people and is a starch with a high proportion of amylose which is higher than other starch sources. It ranks as the second source of starch in the world after the cornstarch. It is primarily used in its native state but can also be used modified through different treatments to improve their consistency properties, viscosity, stability to changes in $\mathrm{pH}$ and temperature, gelation and dispersion, so it can be used in various commercial applications $[17,18]$.

Hydrocolloids are substances that are used as additives for the purpose of reproducing similar viscoelastic properties to the gluten. They are water-soluble polysaccharides, with varied chemical structures that confer certain properties that make it of a suitable functional application [13].

Another compound that has been studied is the glycerylmonostearate (GMS) through the physicochemical, rheological and textural properties in noodles made with corn starch and potato starch. These noodles exhibited a longer baking time and a reduced weight. In turn, the analysis of the texture after cooking, it is revealed that noodles are slightly softer, but more cohesive and gummy when GMS is used [19].

The aim of this work was to select starches and hydrocolloids suitable to produce premixes that allow making noodles suitable for celiac people and evaluate their physical, chemical and sensorial characteristics.

\section{Material and Methods}

\subsection{Materials}

PERLA corn starch $[13.1 \%$ moisture, $0.10 \%$ protein $(\%$ $\mathrm{N} \times$ 5.7), 58-65 ${ }^{\circ} \mathrm{C}$ gelatinization temperature] was obtained from Industrias de Maíz S.A., Buenos Aires, Argentina. ALDEMAN cassava starch [13.5\% moisture, $0.10 \%$ protein $(\% \mathrm{~N} \times 6.25), 55-63{ }^{\circ} \mathrm{C}$ gelatinization temperature] was from Cooperativa Agrícola Industrial San Alberto Ltda., Misiones, Argentina. TRIMACER rice flour [13.5\% moisture, $6.2 \%$ protein $(\% \mathrm{~N} \times 6.25), 65-72{ }^{\circ} \mathrm{C}$ gelatinization temperature] was a product of Atilio Betella y Cía, Santa Fe, Argentina. Pregelatinized cornstarch GLUTAGEL "NT", [8\% moisture; $0.2 \%$ protein ( $\mathrm{N} \times 5.7)$; Brookfield viscosity cold-gel at a concentration of $8 \%$ and 100 rpm: 800-1600 cp, was from Glutal SA, Esperanza, Argentina.

Hydroxypropylmethylcellulose (HPMC) (2\% viscosity: 3000-5600 cp) was from The Dow Chemical Company,
Midland, Michigan, USA. Xanthan gum (1\% viscosity $1400-1600 \mathrm{cp})$. Guar gum (1\% viscosity $3000 \mathrm{cp}$ ) was from Chemistry Oeste, Buenos Aires, Argentina. Egg powder (3\% moisture; $43 \%$ protein) provided by Poultry Company Inc., Santa Fe, Argentina.

Equipment used included an Oster mixer with two stainless steel whisks at $400 \mathrm{rpm}$. The apparatus used to laminate and cut the dough was Top House Model QF 150.

\subsection{Noodle Manufacture}

Noodles were manufactured according to the formulation selected in previous assays [20] and it is shown in Table 1. Type of corn starch and type and level of hydrocolloid were used as variables.

Table 1. Formulation for gluten free noodle.

\begin{tabular}{|c|c|c|}
\hline Raw material & Quantity (g) & Proportion \\
\hline Cassava starch & 97.5 & 65 \\
\hline Rice flour & 30.5 & 20 \\
\hline Corn starch & 22.5 & 15 \\
\hline Egg powder & 22.5 & 15 \\
\hline Hydrocolloid & 3.0 & 2 \\
\hline Salt & 3.0 & 2 \\
\hline Water & 78.0 & 52 \\
\hline
\end{tabular}

Powder ingredients (corn starch, rice flour, cassava starch, hydrocolloid, egg powder and salt, were mixed at $400 \mathrm{rpm}$ for $1 \mathrm{~min}$. Water was added and then two minutes of mixing until achieve the formation of pellets. Then the dough was laminated gradually decreasing the spacing of the rollers, from the position $1(4 \mathrm{~mm})$ to the position 7 $(1.5 \mathrm{~mm})$. Once the dough was sheeted to a thickness of 1.5 $\mathrm{mm}$ was cut into wide strips using the same Top House laminator with the appropriate fixture for cutting and so obtains the noodles.

\subsection{Noodle Evaluation}

\subsubsection{Machinability}

The difficulty in the dough formation was evaluated taking account the type and proportion of the ingredients studied in this work. The dough may be wet, may be elastic and may change its stickiness in hands or in working materials. Furthermore, the difficulty in the laminate is added; since the stickiness of the dough may result in the adhesion to the rolls of the laminator, complicating this stage of progressively decrease its thickness.

\subsubsection{Moisture}

It is determined at $105^{\circ} \mathrm{C}$ for 24 hours, weighing $3-5 \mathrm{~g}$ of sample. The determinations were performed in duplicate and the moisture values emerged using the following equation: Moisture $(\%)=[$ (weight of wet noodle - weight of dry noodle) / weight of wet noodle] x 100 .

\subsubsection{Loss of Solids by Cooking}

The loss of dispersed solids in the cooking water is widely used as an indicator of cooking quality of noodles, considering that the low solids loss is an indicative of its 
high cooking quality [21,22]. In our work and according to previous experiences, cooking losses were determined in duplicate at optimal cooking time: five minutes. For each test $15 \mathrm{~g}$ of noodles were introduced into a container with $150 \mathrm{ml}$ boiling water. After the time selected, the sample was drained and washed three times with $10 \mathrm{ml}$ of water at $20^{\circ} \mathrm{C}$. This washing water was added to the water cooking. An aliquot of $25 \mathrm{ml}$ was taken from the total volume of water in which the amount of solids was determined by evaporation at $105^{\circ} \mathrm{C}$ during 24 hours. The amount of solids was referred to the original sample according to the following equation: Loss by cooking $=$ (weight of total solids in the cooking water and washing / dry weight of noodles before cooking) x 100 .

\subsubsection{Sensory Analysis}

Firmness, elasticity, compressibility and stickiness were considered for textural evaluation. The combination of these factors leads to a good estimate of their textural characteristics. These sensorial determinations are important equal as physical measurements, especially when developing new products [23]. The Instrumental tests are also considered useful tools to evaluate the texture when there are changes in formulations, raw materials or processing applied to noodles [24]. In our work, noodles obtained in experimental tests were subjected to scoring to determine their physical characteristics on a comparative basis. Experts in a number of four scored the individual characteristics of the noodles which were related to those of a hypothetical standard noodle. Each sample was served at the same time after they were cooked. Experts scored each sample once and assigned scores on a scale of 1-10 for texture (firmness, chewiness and stickiness) and taste. The scale of values established was: Excellent (9-10), Very Good (8-9), Good (7-8), Regular (6-7), Fair (5-6), Very Poor (4 - 5) and Unacceptable (1 - 4).

\subsection{Statistical Analysis}

Analysis of variance (ANOVA) was performed and the mean values of triplicates were compared to establish significant differences at $\mathrm{p}<0.05$, according to the method of Duncan's Multiple Range.

\section{Results and Discussion}

\subsection{Starch Selection}

At this stage we worked on the selection from cornstarch, for this motive native corn starch and pregelatinized corn starch were tested. The proposed formulation which provides a $2 \%$ guar gum was used. Barrios et al. [25] found that native starches are not appropriate to fulfil certain functions in foods, making convenient to modify them so as to develop a new class of derivatives which are suitable for specific purposes and achieve diversify use properties. Meanwhile, Aristizabal and Sanchez [17] established that the modification of starch can enhance or inhibit properties such as consistency, binding power, stability to changes in $\mathrm{pH}$ and temperature, and also improve their ability to gelation and dispersion in aqueous medium.

In our work, with native and pregelatinized corn starch no significant differences for solids loss were found at a significance level of $0.05(\mathrm{~F}=1.77)$, but we could find differences significant statistically between the mean values of moisture as shown in Figure $1(\mathrm{~F}=90.11)$.

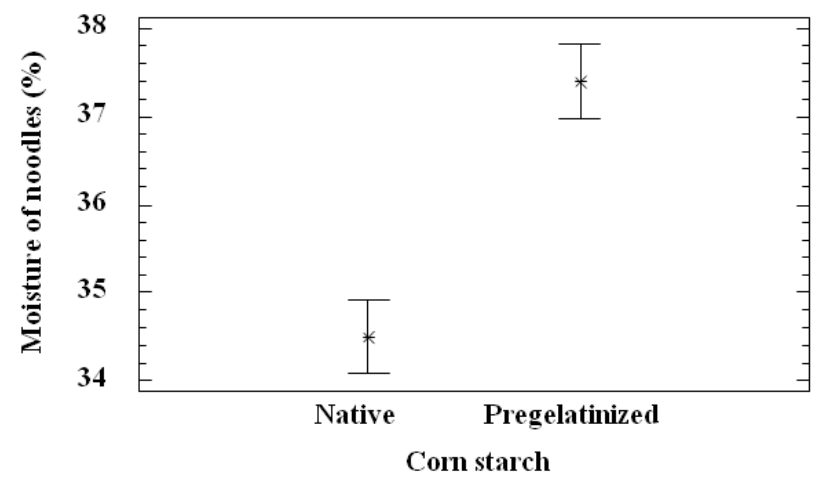

Figure 1. Moisture of noodles made with native and pregelatinized corn starch.

Regarding the dough's machinability obtained with both starches, it was clearly noted that the dough prepared with native starch produced a poor integration of components, which was reflected in dry and crumbly dough. Instead, the dough prepared with pregelatinized starch had no problem in the integration of ingredients, resulting uniform and wet dough devoid of stickiness, thereby facilitating the rolling process.

As for the sensory evaluation, noodles obtained with native starch were soft and inclined to crumble, however, those made with pregelatinized starch were acceptable, with a smooth surface and chewiness defined as "al dente". Finally, according to the mentioned advantages the pregelatinized corn starch was selected as the most appropriate for use in the formulation of gluten free noodles.

\subsection{Hydrocolloid Selection}

At this stage we worked on the selection of hydrocolloids, for this motive guar gum, HPMC and xanthan gum were tested in triplicate. As proposed in the formulation (Table 1) they were used at a level of $2 \%$ and besides, the pregelatinized corn starch was selected to noodle manufacture.

Significant differences in values of moisture, of loss of solids by cooking and of taste and texture score at a significance level of 0.05 were found. Table 2 shows the mean values and the result of applying Duncan multiple range tests. 
Table 2. Moisture, machinability, loss by cooking, taste and texture of noodles made with different hydrocolloids.

\begin{tabular}{llllll}
\hline Hydrocolloid 2\% & Moisture \% & Machinability & Loss by cooking (\%) & Taste(Score) & Texture(Score) \\
\hline Xanthan gum & $34,8 \mathrm{a}$ & brittle dough & $7,02 \mathrm{~b}$ & $6.0 \mathrm{~b}$ & $7.4 \mathrm{~b}$ \\
Guar gum & $34,5 \mathrm{a}$ & malleable dough & $6,09 \mathrm{c}$ & $8.5 \mathrm{a}$ & $9.1 \mathrm{a}$ \\
HPMC & $33,4 \mathrm{~b}$ & very brittle dough & $8,81 \mathrm{a}$ & $6.5 \mathrm{~b}$ & $6.5 \mathrm{c}$ \\
\hline
\end{tabular}

Different letters indicate significant differences $(\mathrm{p}<0.05)$

Based on these results, it is seen that the moisture of noodles is similar when guar gum and xanthan gum are used. However, when using HPMC the noodle moisture value is lower, resulting more brittle product. Moreover, if we analyze the loss of solids by cooking, a reduction statistically significant is obtained when using guar gum (Table 2).

As for machinability, there were differences in the handling of the dough. When guar gum is used, the dough is easily assembled, being malleable and no sticky, when worked with xanthan gum, the dough was homogeneous but very difficult to laminate resulting a brittle dough, finally when HPMC was used the dough obtained was less wet and even more difficult to integrate the ingredients. Lazaridou et al. [26] have established that a high elasticity was observed when xanthan was added to a rice flour blend but we found a better behaviour of this elasticity using guar gum in the formulation.
According to the obtained results, guar gum is the best hydrocolloid to be used in testing noodles for celiac because of its better technological behaviour, to be the most economical and widely available in the market. It can be added to these comparative advantages the fact that noodles prepared with guar gum give a consistency "al dente" after cooking with 9.1 as texture score and 8.5 as taste score, while noodles obtained with xanthan gum and HPMC give a consistency soft and sticky, with 7.4 and 6.5 as texture score and 6 and 6.5 as taste score respectively (Table 2).

\subsection{Guar Gum Level}

Noodles were made with the following levels of guar gum: $1 \%, 2 \%$ y $3 \%$, using the proposed formulation with the selected pregelatinized corn starch.

Table 3. Machinability, loss by cooking, taste and texture of noodles made with different levels of guar gum.

\begin{tabular}{llllll}
\hline Guar Gum (\%) & Machinability & Loss by cooking (\%) & Taste (Score) & Texture (Score) \\
\hline 1 & sticky dough rough noodles & $6.20 \mathrm{a}$ & 8.5 a Very Good & $5.8 \mathrm{c}$ & Fair \\
2 & malleable dough noodles smooth and uniform & $6.09 \mathrm{a}$ & 8.5 a Very Good & $9.1 \mathrm{a}$ & Excellent \\
3 & hard dough noodles smooth and uniform & $5.90 \mathrm{a}$ & $8.5 \mathrm{a}$ Very Good & $7.3 \mathrm{~b}$ & Good \\
\hline
\end{tabular}

Different letters indicate significant differences $(\mathrm{p}<0.05)$

According to Table 3, it can be seen that the variation in the level of guar gum has no effect on loss by cooking and noodle taste, but at $2 \%$ of substitution level, the machinability has improved and a very good texture was obtained, which was characterized as "al dente". Besides, these noodles were similar to those made with wheat flour (figure 2). Guar gum has the property of producing dough elasticity but $1 \%$ is insufficient and $3 \%$ is excessive. In first case the dough can not obtain enough elasticity while in the second the dough is too tenacious.

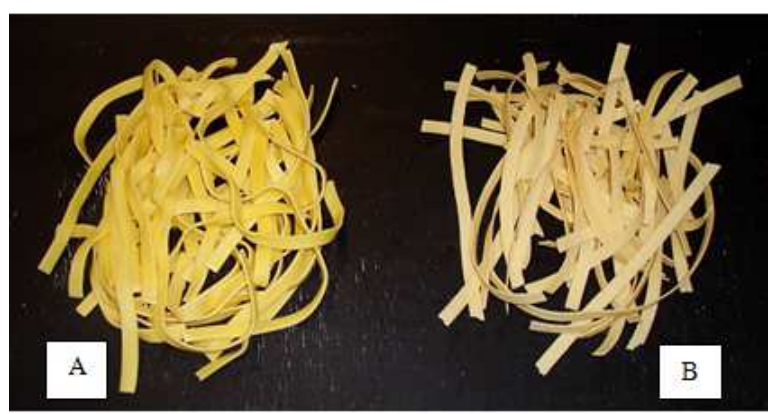

Figure 2. A: Noodles made with wheat flour B: Gluten free noodles with $2 \%$ guar gum.

\section{Conclusions}

Pregelatinized corn starch was selected against native because greatly improves the characteristics of noodles in terms of dough machinability as well as from the sensory standpoint. Furthermore, guar gum was the hydrocolloid most desirable as a consequence of good dough moisture and thereby achieves machinability adequate. Also there is less loss of solids by cooking and with the use of $2 \%$ the best sensory characteristics of noodles are achieved.

\section{References}

[1] Heredia, C., Castro, F. and Palma, J. (2007). Adult celiac disease. Revista Médica de Chile. 135:1186-1194.

[2] Murray, J.A. (1999). The widening spectrum of celiac disease. American Journal of Clinical Nutrition. 69:354-365.

[3] Kawamura-Konishi, Y., Shoda, K., Koga, H. and Honda, Y. (2013). Improvement in gluten-free rice bread quality by protease treatment. Journal of Cereal Science. 58:45-50. 
[4] Gómez, J.C., Selvaggio, G.S., Viola, M., Pizarro, B., la Motta, G. and de Barrio, S. (2001). Prevalence of celiac disease in Argentina: screening an adult population in $\mathrm{La}$ Plata area. The American Journal of Gastroenterology. 96:2700-2704.

[5] Lee, A.R., Ng, D.L., Zivin, J. and Green, P.H. (2007). Economic burden of a gluten-free diet. Journal of Human Nutrition and Dietetics. 20:423-430.

[6] Cueto Rua, E., Nanfito, G. 2004. Enfermedad Celíaca. Intramed. http://www.intramed.net/UserFiles/Files/celiaco.pdf

[7] Del Castillo, V., Lescano, G. and Armada, M. (2009). Formulación de alimentos para celíacos con base en mezclas de harinas de quínoa, cereales y almidones. Archivos Latinoamericanos de Nutrición. 59:332-336.

[8] Granito, M. and Ascanio, V. (2009). Desarrollo transferencia tecnológica de pastas funcionales extendidas con leguminosas. Archivos Latinoamericanos de Nutrición. 59:71-77.

[9] Jenkins, D.J.A., Jenkins, A.L., Wolever, T.M.S., Collier, G.R., Rao, A.V. and Thompson, L.U. (1987). Starchy foods and fibre: reduced rate of digestion and improved carbohydrate metabolism. Scandinavian Journal of Gastroenterology. 22:131-141.

[10] Araya, H., Pak, N., Vera, G. and Alviña, M. (2003). Digestion rate of legume carbohidratos and glycemic index of legume-base meals. Journal of Food Science. 54:119-126.

[11] Granito, M.,Torres, A. and Guerra, M. (2003). Desarrollo y evaluación de una pasta a base de trigo, maíz, yuca y frijol. Interciencia. 28:372-379.

[12] Gallagher, E., Gormley, T.R. and Arendt, E.K. (2004). Review recent advances in the formulation of gluten-free cereal-based products. Trends in Food Science \& Technology. 15:143-152.

[13] Anton, A. and Artfield, S. (2008). Hydrocolloids in glutenfree breads: Review. International Journal of Food Science and Nutrition. 59:11-23.

[14] Demirkesen,L., Mert, B., Sumnu, G. and Sahin, S. (2010). Rheological properties of gluten-free breads formulations. Journal of Food Engineering. 96: 295-303.

[15] FAO (2004). El Arroz y la Nutrición Humana. http://www.fao.org/rice2004/es/f-sheet/hoja3.pdf

[16] Yoenyongbuddhagal, S. and Noomhorm, A. (2002). Effect of physicochemical properties of high-amylose Thai rice flours on vermicelli quality. Cereal Chemistry. 79: 481-485.
[17] Aristizábal, J. and Sánchez, T. (2007). Características del Almidón de Yuca. Capítulo 5:33-34 y Capítulo 6:41-43. Guía técnica para la producción y análisis del almidón de yuca. Boletín de Servicios Agrícolas de la FAO 163.Organización de las Naciones Unidas para la Agricultura y la Alimentación. Roma,Italia. http://www.fao.org/docrep/010/a1028s/a1028s00.HTM

[18] Cueto, D. (2007). Formulación de una mezcla lista para torta a base de harina de trigo y yuca. Tesis de Master. Ingeniería de Alimentos. Universidad de Oriente. Venezuela. http://pscsni.blog.unq.edu.ar/modules/docmanager/index.ph p?curent_dir $=26$

[19] Kaur, L., Sing, J. and Sing, N. (2005). Effect of glycerol monostearate on the physico-chemical, thermal, rheological and noodle making properties of corn and potato starches. Food Hydrocolloids. 19:839-849.

[20] Osella, C.A., de la Torre, M.A. and Sánchez, H.D. (2014). Safe Foods for Celiac People. Food and Nutrition Sciences. 5:787-800.

[21] Del Nobile, M.A., Baiano A., Conte, A., Mocci, G. (2005). Influence of protein content on spaghetti cooking quality. Journal of Cereal Science. 41:347-356.

[22] Manni, D. (2006). Thesis: Elaboración de fideos enriquecidos con distintos concentrados proteicos: Evaluaciones sensoriales y fisicoquímicas. Licenciatura en Biotecnología. Facultad de Bioquímica y Ciencias Biológicas. UNL Santa Fe Argentina. http://www.fbcb.unl.edu.ar/pages/investigacion/tesis/delicenciatura.php

[23] Hoefler, A.C. (2004). Functions and Properties. Capítulo 3, p. 27 in: Hydrocolloids. Edited by Eagan Press. American Association of Cereal Chemist. St. Paul, Minesota, USA.

[24] Ross, A.S. (2006). Review: Instrumental Measurement of Physical Properties of Cooked Asian Wheat Flour Noodles. Cereal Chemistry. 83: 42-51.

[25] Barrios, S.E., Contreras, J.M. and López Carrasquero, F. (2009). Estudio preliminar de modificación química de almidón de yuca mediante reacciones de carboximetilación asistida por microondas. Suplemento de la Revista Latinoamericana de Metalurgia y Materiales. http://rlmm.mt.usb.ve/S02/N1/RLMMart-09502N1p159.pdf

[26] Lazaridou, A., Duta, D., Papageorgiou, M., Belc, N. and Biliaderis, C. (2007). Effects of hydrocolloids on dough rheology and bread quality parameters in gluten-free formulations. Journal of Food Engineering 79:1033-1047. 